RIKKE ANDERSEN KRAGLUND

Ph.d., adjunkt ved Institut for Kultur og Globale Studier, Aalborg Universitet

\title{
UKRONIER I SVEND ÅGE MADSENS FORFATTERSKAB
}

\footnotetext{
NON-MIMETIC SCENARIOS IN SVEND AAGE MADSEN'S WRITINGS | In

2010 the article "Unnatural Narratives, Unnatural Narratology: Beyond Mimetic Models" appeared in the American journal Narrative, where the theory of an 'unnatural narratology' was presented. This theory opposes the claim that the basic elements of narrative can be explained by models based on real-world parameters. According to this theory, narratives that feature impossible or anti-mimetic elements have been marginalized in existing narratological frameworks.

This article discusses some of the concepts that are developed in the first manifesto of unnatural narratology and illustrates the applicability of these concepts in relation to a small selection of the numerous non-mimetic scenarios found in Svend Aage Madsen's works.
}

KEYWORDS | unnatural narratology, narrative theory, Svend Aage Madsen, time, composition, multiversionality, metatext

I bogen Når man mailer (2009) beskriver Svend Åge Madsen sin kamp med at få de snart tusind personer i forfatterskabets værker placeret i et program for slægtsforskning, for programmet vil ikke umiddelbart godtage, at personer eksempelvis kan dø flere gange. Det vil fiktionen heldigvis godt, så i Madsens værker ses personer, der kan overtage andres identitet, skikkelse og ånd, personer, der sammensmeltes, spaltes op i flere, der fødes som dreng, men kan genfødes ugen efter som pige, som adskilles i forskellige kropsdele, som mangler deres skygge, deres spejlbillede eller deres ubevidste. Fortælleteorien har på ingen måde kunnet følge med de rige eksperimenter med protagonister i fiktionen, og det samme gælder fiktionens beskrivelse af non-mimetiske tid og rum. Man har haft problemer med fortællinger, der bevæger sig ud over det mulige i vores egen verden, hvilket ofte har givet fiktionens mulige scenarier en parentetisk plads i narratologiens fortællemodeller.

I 20I0 udkom i det amerikanske tidsskrift Narrative artiklen "Unnatural Narratives, Unnatural Narratology: Beyond Mimetic Models" af Jan Alber, Stefan Iversen, Henrik Skov Nielsen og Brian Richardson, hvor teorien om en 'unaturlig narratologi' blev præsenteret, der skulle tage højde for de mange 'unnatural texts', der er blevet overset eller marginaliseret i narratologiens hidtidige rammer. I denne artikel vil jeg diskutere nogle af de koncepter, der særligt blev udviklet i det første 
manifest om unaturlig narratologi, og belyse disse koncepters anvendelighed i forhold til et mindre udvalg af de utallige non-mimetiske scenarier, man finder $\mathrm{i}$ Svend Åge Madsens forfatterskab.

\section{Unaturlig narratologi}

Præsentationen af en 'unaturlig narratologi' i artiklen "Unnatural Narratives, Unnatural Narratology: Beyond Mimetic Models" indledes med et opgør mod det, man kalder en 'mimetisk reduktionisme', hvor realistiske tekster er blevet set som "prototypiske manifestationer af fortællinger," og hvor fortællinger grundlæggende kan forklares på basis af "real world knowledge" og ved at konsultere kognitive parametre. (Alber et al. II4) Man er enige i, at en række fortællinger udspiller sig i scenarier med en tæt relation til den virkelige verden, men af særlig interesse for en unaturlig narratologi er tekster, der er non-mimetiske, fysisk eller logisk umulige med en udsigelse, en protagonist, eller en verden, der adskiller sig fra, hvad der kan hænde i den virkelige verden. Det kan være tekster, der bryder og udfordrer en traditionel og konventionel "naturlig" og realistisk rammesætning ved at:

"[...] radikalt dekonstruere den antropomorfe fortæller, den traditionelt menneskelige karakter og de bevidstheder, der er associeret til dem, eller som kan bevæge sig ud over den virkelige verdens forestillinger om tid og rum, og dermed tage os til de mest fjerntliggende områder af konceptuelle muligheder.”

Ét af de første argumenter for en unaturlig narratologi har dermed at gøre med materialevalg og metode. Fortælleteorien har ifølge artiklen "Unnatural narratives" overset fortællemuligheder i mere eksperimenterede, non-mimetisk fiktion gennem historien fra "middelalderens drømmevisioner, legende renæssancetekster over science fiction og postmodernisme."2 Forskerne bag den unaturlige narratologi vil undersøge, hvordan eksperimenterede fortællinger udfordrer en mimetisk forståelse af fortællinger, og hvad det betyder for den generelle opfattelse af, hvad en fortælling er og kan. (Alber et al. 115 )

I artiklens indledende præsentation ligger der både en videreførelse og et opgør med flere betydningsfulde narratologer, der ikke direkte ekspliciteres, men indirekte refereres. Som forgangstekster til en unaturlig narratologi henvises til flere af Brian Richardsons værker og artikler, bl.a. Unnatural Voices. Extreme Narration in Modern and Contemporary Fiction fra 2006, hvorfra man overtager en kritik af definitionen af en fortælling som "someone relating a set of events to someone else", idet man i denne definition af 'someone' finder en mimetisk forståelse, der overser en række

I Oversat til dansk fra Alber et al. II4: [...] radically deconstruct the anthropomorphic narrator, the traditional human character, and the minds associated with them, or they may move beyond real-world notions of time and space, thus taking us to the most remote territories of conceptual possibilities.

2 Oversat til dansk fra Alber et al. II4: "[...] medieval dream visions, playful Renaissance texts, science fiction, or postmodernism." 
værker, hvor fortælleren ikke er et menneske, men for eksempel kan være et dyr, en ting eller stemme. ${ }^{3}$ Kritikken henviser indirekte til James Phelan, der repræsenterer en retorisk tilgang til narratologien og i flere indflydelsesrige bøger, artikler og opslagsværker har defineret en fortælling som netop "verbal acts consisting of someone telling someone else that something happened" for eksempel i Reading Narrative: Form, Ethics, Ideologi fra 1984, Narrative as Rhetoric: Technique, Audiences, Ethics, Ideology fra 1996 og i A Companion to Narrative Theory. 4

Et andet opgør, der ikke ekspliciteres i denne artikel, ligger desuden i valget af termen unaturlig ['unnatural'], der kommer som et svar på Monika Fluderniks bog Towards a 'Natural' Narratology fra 1996, hvor naturlige fortællinger bestemmes således:

"Min brug af konceptet 'naturlig' relaterer sig til forestillingen om menneskets 'embodiedness'. Det er fra denne vinkel, at nogle kognitive parametre kan betragtes som "naturlige" i betydningen "naturligt forekommende eller "konstituerende for en prototypisk menneskelig erfaring." Det vil blive fremført, at mundtlige fortællinger (mere præcist: fortælling forstået som spontan, konversationel storytelling) kognitivt korrelerer med perceptionsmæssige parametre af menneskelig erfaring, og at disse parametre er gældende, selv i mere sofistikerede, skriftlige fortællinger."s

Fra et læserperspektiv og på et receptionsorienteret niveau fremhæver Fludernik, at der sker en implicit homologisering af den fiktive og virkelige verden, når vi læser (Fludernik, Towards a 'Natural' Narratology 35) hvilket også fremhæves i artiklen "New Wine in Old Bottles? Voice, Focalization, and New Writing." fra New Literary History (200I): "Når læsere læser narrative tekster, overfører de parametre fra den virkelige verden i læseprocessen og behandler, hvis det overhovedet er muligt, teksten som et eksempel på en fortælling fra den virkelige verden."6 En sådan homologisering har lighed med Wolfgang Isers beskrivelse af, at der sker

3 Et uddrag fra Alber et al. II5: "[...] if a narrative is, as commonly averred, someone relating a set of events to someone else, then this entire way of looking at narrative has to be reconsidered in the light of the numerous ways innovative authors problematize each term of this formula, especially the first one." Henviser til Richardson, Unnatural Voices 5.

4 Phelans definition gentages med variation i Narrative as Rhetoric: Technique, Audiences, Ethics, Ideology: "[...] narrative in rhetorical terms, the act of somebody telling somebody else on a particular occasion for some purpose that something happened." (Phelan, Narrative as Rhetoric 2I8). James Phelan er selvfølgelig ikke den eneste repræsentant for dette udsagn (Richardson henviser f.eks. også til Wolfgang Kaysers Entstehung und Krise des modernen Romans fra 1954).

5 Oversat til dansk fra Fludernik, Towards a 'Natural' Narratology I2: "My use of the concept of the 'natural' relates to a framework of human embodiedness. It is from this angle that some cognitive parameters can be regarded as 'natural' in the sense of 'naturally occurring' or 'constitutive of prototypical human experience.' It will be argued that oral narratives (more precisely: narratives of spontaneous conversational storytelling) cognitively correlate with perceptional parameters of human experience and that these parameters remain in force even in more sophisticated written narratives [...]."

6 Oversat til dansk fra Fludernik, "New Wine in old Bottles?" 623: "When readers read narrative texts, they project real-life parameters into the reading process and, if at all possible, treat the text as a real-life instance of narrating." 
en "normalisering", når man læser som beskrevet i "Tekstens appelstruktur": "Således lader den litterære tekst sig hverken fuldkommen omskrive til den "virkelige verdens" reale objekter eller til læserens erfaringer. Den manglende identitet medfører en vis grad af ubestemthed. Denne ubestemthed vil læseren imidlertid under læseprocessen "normalisere"." (Iser I08) Men Iser gør samtidig opmærksom på, at man ved at læse teksten som "blot og bart spejl" af reale fænomener mister tekstens litterære kvaliteter.

Den unaturlige narratologi sætter spørgsmålstegn ved det grundlag, som den naturlige narratologi bygger på med selve antagelsen af, at alle fortællinger kan forstås med baggrund $i$, hvad en læser på forhånd kender, og at man læser naturaliserende. Artiklen bliver også mere eksplicit et opgør med David Hermans forestilling i Story Logic om, at alle fortællinger kan forstås ud fra de samme kognitive principper og modeller: "[...] et centralt sæt af kognitive principper og parametre støtter forståelsen af alle fortællinger." 7 Artiklen i Narrative plæderer for, at man som læser i forhold til unaturlige fortællinger med fordel kan anvende andre fortolkningsstrategier end dem, man anvender i en hverdagslig kontekst. I artiklens analyser har man udvalgt tre områder af unaturlighed i fortællinger, som man vil undersøge nærmere: unaturlige verdner ["unnatural storyworlds"], unaturlige bevidstheder ["unnatural minds"] og unaturlige udsigelser ["unnatural acts of narrations"]. I det følgende vil jeg opholde mig ved den unaturlige narratologis definition af unaturlige verdner; en definition, der vil blive studeret $i$ forhold til eksempler på tids- og kompositionsstrukturer i Svend Åge Madsens værker.

\section{Unaturlige tidsoplevelser i Madsens forfatterskab}

'Unaturlige verdner' defineres i det indledende manifest som indeholdende fysiske eller logiske umuligheder vedrørende den repræsenterede verdens tidslige og spatiale organisation. Som eksempel nævnes Alejo Carpentiers "Journey Back to the Source", der præsenterer et fysisk umuligt univers ved brug af en omvendt temporalitet. Denne analyse korresponderer som sagt med Brian Richardsons forskning, hvor han i flere artikler og bøger har vist eksempler på nonmimetiske tekster, der udfordrer eksisterende narrative koncepter med værker, der foruden Unnatural Voices (2006) bl.a. tæller Unlikely Stories (1997), og artikler som "Beyond the Poetics of Plot" (2005) og "Beyond Story and Dicourse: Narrative Time in Postmodern and Nonmimetic Fiction" (2002). I sidstnævnte artikel fremhæver Richardson, at opslagsværker i narratologi og litteraturteori har haft en tendens til at overbetone naturlige eksempler, når det gælder narrativ tid:

Den begrebslige standardramme er her Genettes med dens grundbegreber om orden, varighed og frekvens [...]. Genettes model deler [...] den generelle mimetiske

7 Henvisning til David Herman, Story Logic 4I7: "[...] a core set of cognitive principles and parameters supports comprehension" of all narratives." 
præmis med praktisk talt alle aktuelle teorier om narrativ tid - en fælles grund, der tillader teorien at søge at dække både fiktive og nonfiktive arbejder. I de fleste tilfælde er dette alt, hvad der er nødvendigt. Der er ingen tvivl om, at Genettes redegørelse er adækvat med henblik på at beskrive tidsligheden i de fleste nonfiktive fortællinger, i hovedparten af den realistiske fiktions værker og i megen modernistisk fiktion. [...] Men anvendt på en række senmodernistiske og postmoderne tekster svigter disse kategorier, for de arbejder med distinktioner, som eksperimenterende forfattere insisterer på at udelukke, benægte eller blande sammen [...]. ${ }^{8}$

Richardson peger på seks tidsformer, der er karakteristiske for senmodernistiske og postmoderne værker (men ikke udelukkende), seks former, der bryder med en realistisk temporalitet og gør sig særligt gældende i fiktion. Det er brugen af en cirkular (circular) form, hvor fortællingen ikke afsluttes, men kan vende tilbage til sit udgangspunkt i en uendelig struktur. Den kontrakdiktoriske (contradictory), hvor der gives uforenelige versioner af en historie. Den antinomiske (antinomic), hvor fortællingen samtidigt bevæger sig simultant både forlæns og baglæns i tid. Den differentielle (differential), hvor tiden for nogle personer i historien kan foregå i et andet tempo end andres (f.eks. Woolfs Orlando). Der er den sammensmeltede (conflated), hvor ellers adskilte tidszoner smitter af på hinanden og den to- eller flerfoldige (duel or multiple), hvor forskellige plotlinjer, der begynder og slutter på samme tid, kan tage et forskelligt antal dage at udfolde. (Richardson, Narrative Dynamics 5I)

Ser man på Svend Åge Madsens forfatterskab, så eksperimenteres der med flere af de anførte unaturlige tidsligheder, og det viser i helt usædvanlig grad eksempler på fysiske umuligheder, hvad angår de repræsenterede verdners tid og rum. Mange af de tidsbegrænsninger, man finder med naturlovene $\mathrm{i}$ vores virkelige verden, har løst sig i Madsens univers.

I flere fortællinger skildres eksempelvis en usædvanlig mulighed for at se fortidens hændelser før kameraets opståen, idet spejlplaneter sender fortidens hændelser tilbage til jorden, hvilket bl.a. får en rolle i romanen At fortclle menneskene (I989):

"Tøger så den blinde astronom Adam dEden på sin indre stjernehimmel udpege spejlplaneten Mnemosyne for dem. Han så menneskene rette deres antenner i den anviste retning, indtil de blev i stand til at trække deres egen fortid ned. Han så dem begrave sig i signalerne fra det forgangne. De begyndte at omgive sig med spejlbølger, de lod sig indfange af dem, de slukkede for deres egen verden og levede

8 Oversat til dansk fra Richardson, Narrative Dynamics 47: "The standard conceptual framework here is Genette's, with its basic concepts of order, duration, and frequency. [...] Genette's model [...] shares the same general mimetic assumptions of virtually every other current theory of narrative time, a common ground that allows the theory to attempt to cover both fictional and nonfictional works. In most cases, this is all that is required. There is no question that Genette's account is generally adequate to describe the temporality of most nonfictional narratives, of the great majority of works of realistic fiction, and of much modernist fiction. [...] However, these categories do not work if applied to many late modernist and postmodernist texts, since they are predicated on distinctions that experimental writers are determined to preclude, deny, or confound [...].” 
blandt billederne. [...]. Hver time åd de sig overmætte i fortællinger om en tid der allerede var død. Så mange billeder og historier indtog de, at de var ude af stand til at fordøje dem i samme takt, og de blev tykkere og tykkere inde i hovederne, mere og mere fortællingsforædte, så de mistede evnen til at bevæge deres egne tanker, ude af stand til at flytte et billede, eller presse en idé ind mellem historiedellerne. De begyndte at svulme op af fiktionsfedme, først hovederne som sprængtes, og ud væltede ord og orme som vred sig, blændede af lyset, forvirrede af luften og det store tomme rum omkring dem." (Madsen, At fortalle menneskene 314-315)9

Således kan man også i romanen Mange sæere ting for (2009) få den sande beretning om Jesu liv fra spejlplaneten Aletheia, hvis billeder har været 2000 år undervejs. I tilfældet med spejlplaneterne er det universets indretning, der rummer andre muligheder end i den virkelige verden, men også karaktererne i Madsens univers har en usædvanlig adgang til fortiden som Didrik Dinessøn, der falder ud over en klippekant og både genoplever hele sit eget liv, men dernæst andre af slægtens mænds historie:

"[...] i et evigt øjeblik åbnede sig et indblik i hele slægtens historie. Herunder genoplevede han en forfars hovedløse styrt fra et tårn efter at have set kimen til sin egen skandalehistorie blive lagt." (Madsen, Syv aldres galskab 349)

Didrik Dinessøn Skonning er del af en ekstraordinær slægt, der har en speciel relation til tid, hvilket beskrives i Syv aldres galskab (1994). Didriks tipoldefar er bogtrykkeren Hans Skonning, der lever i I60o-tallets Aars og får en vision af paradis, som læseren kan genkende som Århus i 9o'erne. Den modtagne vision er for Hans Skonning af magisk karakter, men opleves af læseren som en helt naturlig beskrivelse for eksempel af det at slukke lyset:

"Den unge mand forlader rummet. Han løfter hånden for at påkalde mørket og straks kommer det væltende. Uden tøven besætter mørket hele rummet, der for et øjeblik siden henlå klart for dagen. Så sikker er han på sin magt at han ikke engang vender sig for at sikre at mørket har opfyldt hele rummet, sådan som han åbenbart ønsker.” (Madsen, Syv aldres galskab 59)

Også det at tale i telefon antager fra det fortidige en unaturlig karakter: "Det er en pige han taler med. Han har fremmanet hendes ånd uden at hendes krop er til stede." (Madsen, Syv aldres galskab 62). Disse eksempler illustrerer, at forståelsen af 'det unaturlige' kan forandres over tid, og det fremmedgjorte blik fra fortiden gør

9 I novellen "Mnemosynes børn” fra novellesamlingen Mellem bimmel og jord (1990) kan man også modtage avisen For-Posten, hvor man kan få klar viden om, hvad der præcis skete I6. april 55 f.v.t., idet man modtager spejlbilleder fra jorden fra planeten Mnemosyne. 
nutidens realisme humoristisk. ${ }^{\text {o }}$ Den unge mand, Hans Skonning ser i sine syner, er Styge Skonning, der efterforsker sin slægts historie tilbage til Hans Skonning. Styge og Hans Skonning kommer gensidigt til at fortælle hinandens og slægtens historie. De kan bl.a. berette om Hans Skonnings barnebarn Ambrosius Frithger Skonning, der får et usædvanligt forhold til kvinden Karen Fraser, idet de lever i forskellige tidsplaner, der er forskudt fra hinanden:

“"Hvordan kan det være at du var en ung mand da jeg først traf dig, en dreng anden gang, og nu pludselig en gammel mand?” [...] Det var efter at hun var forsvundet igen, at han utydeligt indså, at tiden var den fjerde dimension han så ihærdigt havde søgt livet igennem. Og når hans møder med Karen var så spredte og springende, skyldtes det at de begge var tredimensionale mennesker, hvis tidsplaner var forskudt for hinanden, sådan at de kun lejlighedsvis kom i kontakt. Med hænderne demonstrerede Styge hvordan to krumme flader kun stedvis berørte hinanden.” (Madsen, Syv aldres galskab 43I)

Ambrosius får desuden fremstillet en opskrift på tid, der eksploderer, og en damp trænger ud over byen, så byen rammes af kollektivt hukommelsestab. Det er Ambrosius' barnebarn Didrik, der ser hele slægtens historie under et fald. Didriks egen søns historie bliver ikke mindre usædvanlig. Ernst Didriksøn, der lever et lidt forudsigeligt liv som urmager, kan i drømme få lov til at være de forskellige personer i slægten og får dermed også en usædvanlig adgang til både fortid og nutid:

"I lighed med doktor Faustus havde han fået magt til at oplive fortid og fremtid, og som straf for dette vellevned måtte han, i lighed med den evige jøde, utrættelig, og formodentlig til evig tid, vandre omkring i denne langtudtrukne slægt, ikke i nord og syd, men snart i renæssancen, snart i halvfemserne, for derefter at vågne op i rokokoen, og uden mønster springe til barokken, derpå nutiden, det vil sige dét vi tillader os at kalde nutiden." (Madsen, Syv aldres galskab 373)

Ernsts drømmemuligheder synes dog langt at foretrække i forhold til den tid, sønnen René Skonning må leve efter, hvilket betegnes som et levende bankospil. Fra René er treogtyve, kommer han til at springe ukontrollabelt i tid uden at ane, hvilken alder han har, når han vågner. For omgivelserne lever han et almindeligt kronologisk fremadskridende liv og kommer derfor til at virke som en lidt særpræget person:

"Det medførte at han blev opfattet som en lidt excentrisk, åndsfraværende person, der af og til havde anelser, eller noget der lignede indsigt i de kommende hændelser [...]. På den anden side havde han ofte vanskeligt ved at erindre hvad der var sket $\mathrm{i}$ den nærmeste fortid, set med andres øjne, og omtalte gårsdagens hændelser som

Io I Tugt og utugt i mellemtiden (1976) udnytter Svend Åge Madsen samme fremmedgørelsesteknik, men her er det i stedet en fortæller fra fremtiden - Ato Vari, der med forundring ser på 70’ernes Århus. 
om han havde oplevet dem i en fjern, næsten glemt, fortid, eller måske endnu slet ikke havde stiftet bekendtskab med dem." (Madsen, Syv aldres galskab 280-28I)

Hvor nogle af slægtens medlemmer oplever en ny frihed med visioner om andres liv, så er det svært at se sin egen fremtid forudsagt til mindste detalje som med Elias Nikolaj Skonning, der finder en række sedler, faren har skrevet, der fuldstændig forudsiger alle de hændelser, han siden oplever i en art guddommelig imperativ:

“'Lad Elias træffe Flakballes endnu unavngivne datter. Uanset hvilket navn de måtte tildele hende, lad de to mødes under gunstige omstændigheder.” [...]

- Gik de alle i opfyldelse?

- Jeg er ikke stødt på nogen som ikke blev fuldført, sådan som de var skitserede. [...]

"Skjul disse papirer godt. Hvis Elias læser dem, bliver de hans død."

- Jeg ved ikke hvor mange af sedlerne fra stakken far nåede at læse. Men i hvert fald denne, for da jeg kom hjem og fandt ham død i sin stol, knugede han stadig dette papir i hånden." (Madsen, Syv aldres galskab II9-I2I)

Flere personer oplever også en forskudt tidslighed i forhold til livet omkring dem, hvad Brian Richardson som tidligere anført kalder differentieret tid. I Syv aldres galskab bliver kvinden Charlotte Fuhl ramt af modsot, der gør, at minutter bliver til dage, og hver time lægger et år til hendes alder:

"Efter en dag, en nat og endnu en dag, altså i jordisk mål, kunne hun, der den foregående morgen havde været i sin bedste alder og let til bens, da hun gik ud for at plukke vild asparges - hun var, sagt med al respekt, en ren djævel til at finde vild asparges, var hun - omsider sovet ind, mæt af dage, gammel og mødig på sjæl og krop." (Madsen, Syv aldres galskab 444)"ᄑ

I Charlotte Fuhls tilfælde er det tiden, der griber uforvarende ind i hendes liv, men i Madsens værker er der også et rigt raritetskabinet af videnskabsmænd, der selv forsøger at mestre tiden som Sverre Fuhl fra At fortelle menneskene:

"Han experimenterede med tidslammere, med tidsbindere, med tøveglas, som kun lader lyset passere langsomt igennem sig og dermed opholder tiden, med tidsrør, som var i stand til at udslette de seneste dage, med tidsspejlinger, som han udviklede da han havde modtaget de første billeder fra planeten Mnemosyne, der genudsender jordens historie, han undersøgte tidslommer, og bandt med stor akkuratesse ganske små tidssløjfer.

II Der er utallige eksempler på karakterer i Svend Åge Madsens forfatterskab, som overmandes af tiden som kvinden Anni Osgren, der forsøger at holde sig ung, men til sidst ældes på en enkelt nat i Dr. Strangula (1985). Også Troels Fraser fra Den usynlige myre (1995) bliver pludselig gammel, hvorimod Erling fra Se dagens lys (1980) efter et motorcykeluheld forbliver ung og smuk at se på. Jan Fældings liv går også i stå efter mødet med en kvinde i At fortalle menneskene (1989). 
Han trængte dybt ind i den ny videnskab, som siden skulle kaldes fremtidsarkæologi, og udviklede nye metoder inden for denne. Han konstruerede en tidsring, som imidlertid kun havde en ganske kort rækkevidde, som altid førte tilbage og aldrig frem.” (Madsen, At fortclle menneskene 213)

Det lykkes Sverre at få adgang til fremtiden, men det er dog langt fra lykken. Han føler sig snarere fremtidsplaget, som vi får blik for i Sverres samtale med kvinden Felia med det samme problem i Mange sare ting for: "Når man har modtaget fremtidsgaven, kommer man til at hungre efter nutiden, fortalte de hinanden, og behøvede det ikke, for den ene vidste at den anden ville sige det." (Madsen, Mange sare ting for 85). Adgangen til fremtiden beskrives også i Lad tiden gå (I986), hvor Sverre igen spiller en vigtig rolle. Her møder vi forskeren i kronofysik Dr. Jeyde, der opfinder

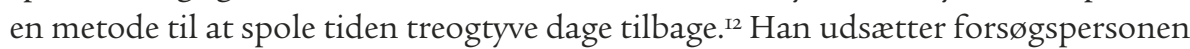
Johanne Fraser for disse tidsspring efter at have præget hendes sind med tortur, men heller ikke Johanne kan udnytte sin viden om fremtiden positivt, og hun beslutter sig for at dræbe sig selv og professor Jeyde, for at hemmeligheden om metoden kan forblive skjult, og man kan slippe ud af gentagelsernes hvirvel. Men forinden har Sverre opfanget metoden og etableret en lang række af tilbagespring, der bestemmer Johannes handlinger.

At være fanget i gentagelsens hvirvel som Johanne i Lad tiden gå synes flere personer at erfare i Madsens værker, hvor der er flere eksempler på cirkulær tid som i Syv aldres galskab, hvor Hans Skonning og Bertel Helled begge har fornemmelsen af, at tiden går i ring. En oplevelse, som et blik på deres samtale bekræfter:

"Hans åbenbaringer fortsatte tilsyneladende i en stadig, om end langsommere flydende, strøm.

- Det sidste blev for meget for dig, gryntede han selvbehageligt. - Du måtte hen og se om ånden har forladt mig. Men du kan berolige dig. Proppen i min hovedskal holder stadig.

$[\ldots]$

- Kender du ikke den oplevelse af det hele er gået i stå? Intet nyt sker, det hele er en gentagelse af en gentagelse.

$[\ldots]$

Tiden er gået i stå. Næsten ikke til at rokke ud af stedet. [...]

$[\ldots]$

Hans åbenbaringer fortsatte tilsyneladende i en stadig, om end langsommere flydende, strøm.

- Det sidste blev for meget for dig, gryntede han selvbehageligt. - Du måtte hen og se om ånden har forladt mig. Men du kan berolige dig. Proppen i min hovedskal holder stadig...”

(Madsen, Syv aldres galskab 320-327)

I2 Jeydes opfindelse gør, at han kan forudsige fremtiden, hvilket han udnytter som Dr. Strangula i Dr. Strangula. 
Det usædvanlige ved Svend Åge Madsens forfatterskab er, at de eksperimenter med tid, der sker i én roman, ofte får konsekvenser for hele Madsens fortælleunivers. Indtil videre har vi set eksempler på tidsspring med adgang til egen og andres fortid og fremtid, differentielle tidsoplevelser mellem karakterer i det samme univers og cirkulære tidsrum eller loops. Derudover er der i Madsens univers også en udbredt brug af parallelle tider, hvor man kan opleve flere forskellige versioner af det samme tidsrum. I flere værker peges der mod, at en fremtidig verden er spaltet i flere versioner som i novellen "Den gode ring" fra Maskeballet (I970), hvor Stig får lov at opleve fire samtidige modeller af jorden og vælge, hvor han helst vil befinde sig. En oplevelse af, at tiden er spaltet ud i flere muligheder, erfares også af Jesper i den Den ugudelige Farce, hvor det ubevidste slår fra:

"Tiden Tiden var var løbet knap, fra lufthavnsbussen ham. ville Hvis ikke ikke vente. han Med skyndte omhu sig pakkede ville han Mabel Raquel komme ned til i at kufferthjørnet. stå Olympia måbende skubbede og han fortabt ind i på lufthavnen, dens hvor plads hun under måtte sengen. se Af $\mathrm{i}$ irritation øjnene over at hvad hun han var måtte ført give $i$ afkald fordærv, på, gjort blev svanger sparket og så siden hårdt skammelig at svigtet han af måtte den sætte listige sig, forfører. sammenkrympet." (Madsen, Den ugudelige Farce I7)

Samtidigheden markeres her i skriften, hvor der skiftes mellem de to muligheder som læseren må forsøge at veksle mellem. At se sig selv spaltet og samtidig afprøve flere muligheder nævnes også i forhold til Tobias Gortis i Syv aldres galskab:

"Tobias har lyst til at følge efter, men i det samme begynder der at ske noget nyt med opstillingen. Uden at mærke det spaltes han, han sætter efter Vibeke, og han følger med bekymring den nye udvikling i opstillingen. Som at se ind i en kegle af muligheder. En svimmelhed som om han afrunder et liv, fortsætter i et nyt lag, oven på det gamle.” (Madsen, Syv aldres galskab 502)

Den udspaltede tid beskrives i Syv aldres galskab som kendetegnende for en syvende alder. De mange unaturlige muligheder i forhold til tid placeres i Syv aldres gal$s k a b$ i en ramme, der beskriver syv forskellige aldre i universet. Dermed gives der en baggrundshistorie til flere af de forskellige tider, som udfolder sig i Madsens andre værker. Den første alder beskrives her som mindernes tid, den anden alder som papirets, den tredje tid er en tredimensionel tid, hvor personerne på papiret rejser sig, den fjerde kaldes fastholdelsens tid, den femte udskiftningssamfundet, den sjette pluravers og den syvende vers.

Den femte alder omkring udskiftningssamfundet kendes for eksempel fra romanen Se dagens lys, hvor personerne ikke kan huske dagen i går, men hver morgen vågner op i en ny situation med nye venner og familie. Dermed har man ikke nogen at dele erindringer med eller mulighed for at lære af gentagelser. Så hvor problemerne med at kende fremtiden blev beskrevet med tilbagespolingerne i Lad tiden 
gå, så er problemet med ikke at kende fortiden tematiseret i Se dagens lys. Madsens værker fortolker hinanden gensidigt, og i Syv aldres galskab forklares overgangen fra fastholdelsens tid, til udskiftningssamfundet og til pluravers således:

"I den fjerde alder, som af nogen kaldes fastholdelsens tid, hvor almanakken stadig var den herskende, blev menneskene grebet af rastløshedens feber. Hidtil havde man været ét menneske, livet igennem, levet én tilværelse, ét sted, ét arbejde, én familie. Men havde efterhånden stadig vanskeligere ved at holde fast. Da gav de sig til at leve to liv ad gangen for at skjule deres rodløshed. [...] - Og da det ikke længere rakte, blev de to til fire, for at holde meningsløsheden stangen. Herefter fire blev til otte, for at øge oplevelsesfylden. Begærligt og umætteligt spredte man sig, indtil man omsider nåede grænsen, og levede et nyt liv hver dag. Sådan at hvert menneske på et år nåede igennem tre hundrede og femogtres liv. Andre siger at glemsomheden kom først. At man hver dag vågnede fyldt af salig glemsel, uden tilknytning til den foregående dag, tom og parat til at leve som om det var livets første dag. [...] Glemslen var den nåde, der gav hver dag nyt indhold. Hvilket var en fælde, for intet nyt kunne opstå, når ingen dag havde noget at sammenligne med. Ingen fornyelse, ingen ændring, ingen udvikling, kun det samme spil, med de samme brikker, rystet, i en ny position. [...] Uset af Lethe spirede imidlertid en interesse for fortiden frem. En interesse for tiden før glemslen. Som endelig, efter mange forgæves tilløb, fik folk til at forlade det evigtvarende, evigtgentagende spil, for i stedet at flytte ind i tidsenklaver." (Madsen, Syv aldres galskab 470-47I)

Efter udskiftningssamfundet flytter folk ind i forskellige tidszoner eller tidsenklaver som renæssancen, stenalderen og oplysningstiden, og tiden i disse tidsenklaver begynder at komme længere og længere fra hinanden, idet tempoet i de enkelte enklaver har forskellige tempi, hvilket man i forhold til Richardsons begrebsapparat kunne kalde endnu et eksempel på en differentiel tid:

"Sådan voksede tiden ud i mange forskellige forgreninger, som træet der i en lang periode vokser samlet, i én bestemt retning, i form af en stamme. Men pludselig skifter det mening og begynder at udbrede sig til alle sider, i et utal af grene." (Madsen, Syv aldres galskab 474)

De forskellige tidsenklaver er adskilt ved tidsmure, som det i Syv aldres galskab lykkes Bertel Helled at bryde gennem, så han fra I60o-tallets Århus kommer til I99o'ernes:

"Med en overmenneskelig anstrengelse besejrede han tidsmuren. Nåede, som ved et mirakel, op på kanten, og lod sig falde ned på den anden side. Frelst.

$[\ldots]$

Næppe havde han trukket vejret, før et kæmpeuhyre pludselig for frem mod ham med svimlende hastighed. Han hørte kun det øresønderrivende brøl, og så de kæmpemæssige, lysende øjne, der næsten blændede ham. [...]. Uhyret åbnede sig. 
Ikke gabet. Det havde tilsyneladende slet ikke noget gab. Men siden. Som en lem $i$ siden. Ud af lemmen steg et væsen i underlig beklædning. Men umiskendeligt et menneske." (Madsen, Syv aldres galskab 462-463)

Igen udnytter Madsen muligheden for at lade fortidens blik på et nutidigt scenarie skabe en humoristisk fremmedgørelse. I Syv aldres galskab bliver værkets og universets konstruerede karakter stadig mere udtalt i romanens slutning, hvor Bertels spring over tidsmure også iagttages ovenfra, idet scenariet beskrives som en del af en forsøgsopstilling af en fortællingsverden, der er knyttet til Tobias Gotis' indoptagelse af forskellige hjerner.

"Han vender sig mod den virkeliggjorte globale fortælling. Af og til flimrer billedet, fordi de har været nødt til at begrænse sig til tidsindsnit. Det er en globus befængt med et utal af næsten mikroskopiske kugleformede svampe som alle vrimler med liv. [...].

De er alle sig selv, lever deres egen verden, deres egen tid. Og de er alle samlet, lever deres store fælles fortælling. Pluravers er blevet til Vers.

[...] Lidt adspredt følger han globen der udfolder sig foran ham. Menneskene i den lever i hver deres tid, men kan dog nå hinanden fordi de er forbundet via koglen i hjerneskallen." (Madsen, Syv aldres galskab 50I-502)

I Madsens forfatterskab er det metatekstuelle markant fremtrædende, så læseren undervejs ofte gøres opmærksom på det fortalte univers som et fiktivt univers. Hvorvidt man vælger en 'naturlig' eller 'unaturlig' fortolkningsstrategi, kan have vidtrækkende konsekvenser for forståelsen af Madsens værker f.eks. i forhold til fortælleforhold. I Niels Dalgaards Verdensjongløren bliver en naturlig rammesætning og historisk viden eksempelvis brugt til at bestemme, hvem der skriver hvad i Syv aldres galskab: "Bertel opfordrer Skonning til at skrive sine fremtidssyner ned, og dermed kunne man forestille sig, at hele bogen ikke er Styge Skonnings værk, men Hans Hanssøn Skonnings. Det ville imidlertid forudsætte, at han havde præcise visioner af en tid, han ikke forstår, og kunne skrive dem ned på en for moderne mennesker klar måde (og vi ved fra de tekster, der har overlevet, at virkelighedens trykker Skonning ikke var nogen litterær ørn). Det mest rimelige er altså fortsat at antage, at bogen er Styges værk, idet han jo sagtens kunne have indlagt en forestilling om, at den gamle Skonning fik syner om hans fremtid." (Dalgaard, Verdensjongløren I39) Som læser af Madsens værker må man i udpræget grad være opmærksom på faldgruber ved at foretage sine fortolkninger med virkelighedens rimelighed og sandsynlighed som baggrund.

\section{Rammebrud}

At kortlægge tid i Svend Åge Madsens værker er ofte en vanskelig proces, idet fortid og fremtid sammensmeltes, og personer fra forskellige tider kan møde hinanden. 
Der er i udpræget grad anvendelse af metalepsis eller rammebrud, hvor forskellige diegetiske niveauer sammenblandes. Karaktererne kan eksempelvis se, at de deltager $i$ andres fiktioner. Styge Skonning, der genfortæller slægtens historie i Syv aldres galskab, opdager at være en af Hans Skonnings åbenbaringer. Forbogstaverne på de personer, Styge Skonning har fortalt om, bliver tilsammen: "Hvad der er digtes":

"Det er os, der er hans åbenbaringer. Hans fortællinger. Vi begyndte som papir, men er vokset. Vi har løftet hovedet. [...] - Virkeliggjort. Begyndt som hans syner, men har lagt en dimension til. [...] - Jeg troede jeg søgte min modhistorie til døden. Men min opgave var at rense ham. At fortælle hans modhistorie." (Madsen, Syv aldres galskab 499-500)

I Af sporet er du kommet besøger Vagn Isenborg Bummelmann Stauff bogsamleren Rikkard Duebo Vem og ser, at han optræder i adskillige af Dueboe Vems bøger:

"Han lod mig blade i en tilfældig bog, og jeg så, at hver gang en bestemt bifigur optrådte var hans navn streget over og erstattet med et andet: Vagn Isenborg Bummelman Stauff. [...]

- Hold op! skreg Vagn og smed papirerne fra sig. - Rikkard Duebo Vem. Det er jo os, der har opfundet ham! - Han er åbenbart af en anden mening, sagde Fegge fredsommeligt. - Hvordan kan han påstå at han har opfundet mig? En tilfældig, tom figur, uden nogen mening. Jeg vil ikke være fiktiv!” (Madsen, Af sporet er $d u$ kommet I27-I28)

Næsten samme oplevelse har Garion Siger i Sat verden er til, hvor han læser om sit eget liv i Jeroni Autosefas bogsamling: "Febrilsk finder han frem til titelbladet, hvor der med store kunstfærdige bogstaver står anført: "Garion Sigers Forunderlige og Smukke Liv" (Madsen, Sat verden er til I2). I Sat verden er til er det desuden muligt at optræde i samme verden som sin skaber:

“- Kender du mig ikke? Det er mig der har skabt dig, jeg mener, skrevet alle bøgerne om dig.

- Jeg forstår ikke, indvender Asereser tøvende. Han betragter de andre i selskabet som for at finde bekræftelse for at den anden er utilregnelig." (Madsen, Sat verden er til 312)

Metatekstuelt betones det også, hvorledes man kan bevæge sig fra karakterniveau og til fortællerens udsyn:

"Han mærker at han løfter sig op fra denne jord. Han bevæger sig op til fortælleren, og sammen ser de ned på dette brogede mønster. Herfra kan han se at hans liv udgør et afrundet værk, som ikke ville have været smukt og tilfredsstillende, hvis det skulle have undværet de træk, der set dernede fra virkede som mørke, 
skræmmende pletter. Han ser sit liv som det spor han har tegnet hen over nogle sider, og med glæde mærker han, at han har lyst til at applaudere sit eget værk." (Madsen, Sat verden er til 357)

I Mange sare ting for kan Alian Sandme desuden høre sit liv beskrevet af en fortæller som en art 'fortællertinnitus':

“Jeg vågner ved at en stemme taler. 'Han vågner ved at høre en stemme,' siger den. Jeg sætter mig fortumlet op. Stemmen følger efter: 'Han sætter sig fortumlet op' [...]

Men nu er det overgået mig selv. Selv blevet fortælling. 'Men nu er det overgået ham selv. Selv blevet fortælling." (Madsen, Mange sare ting for 374)

Personerne kan have kendskab til den roman, de indgår i, eller kan have læst historien om deres egne oplevelser før, som Bertel Helled, der derfor kan vælge en forgiftet blomme fra i Syv aldres galskab. ${ }^{13}$ Torbias Gotis opsøger i samme roman psykiateren dr. Monikke, fordi han føler sig som offer for en forfatter, der ikke har begreb om at fortælle. (Madsen, Syv aldres galskab 292) Desuden kender personerne Svend Åge Madsens værker i Syv aldres galskab, hvor Styge Skonning kan fortælle Tobias Gortis om Narrespillet om Magister Bonde og Eline Mortensdatter. (Madsen, Syv aldres galskab 489) I Syv aldres galskab kommenteres også på romanens sammenhæng med andre af Svend Åge Madsens værker:

"Havde man den originale romanglobus i hænde, ville man således umiddelbart kunne se at den fjerne efterkommer efter Didrik, der 'på omtrent samme sted i bjergene oplevede et trehovedet fald', som der så kryptisk står i teksten, blir beskrevet i Hadets bånd.

Ligeledes vil man øjeblikkelig, hvis ens interesse er blevet vakt, fra Styges omtale i afsnit I4 af den profet han en overgang ledsager, kunne følge tråden til Jakkels vandring, hvortil Styge har leveret en skrolle om denne periode af sit liv.

Forlænger man linien fra Tobias' snak om Geo D. Eden, som har stillet lokaler til rådighed for Joakims eksperimenter, vil man i den ene retning havne i At fortælle menneskene og i den anden i Edens Gave." (Madsen, Syv aldres galskab 357)

I hidtil uset grad er Svend Åge Madsens værker med karakterer, fortællere og verdner knyttet sammen i en fælles makrotekst eller 'globusroman', hvor der skrives videre på tidligere fortællinger og antydes kommende. ${ }^{14}$ Henrik Skov Nielsen har $i$ en analyse af Marianne Kainsdatters Blodet på mine honder netop også fremhævet det uafsluttelige som et karakteristisk træk ved forfatterskabet med dets sam-

I3 Andre markante eksempler på personer eller fortællere, der oplever at være konstrueret, ses eksempelvis i Liget og Lysten (I968) og novellen "Af ord er du kommet" fra Maskeballet (1970).

I4 Som særligt Niels Dalgaard har gjort rede for i det imponerende opslagsværk: Dage med Madsen eller Livet $i$ Årbus fra 1996. 
menbundethed mellem de enkelte værker, hvor man møder de samme personer og hændelser fra forskellige vinkler og med stadig flere detaljer. Denne uafsluttelighed bryder med narratologiens fremhævelse af slutningen som et afgørende træk for definitionen af en fortælling:

“[...] en af de få ting, som stort set alle litteraturforskere er enige om, er, at der skal være en slutning. [...] F.eks. mener Peter Brooks, som blev og bliver læst meget på de danske universiteter, at grunden til, at vi mennesker overhovedet læser, er, at vi har et begær efter at nå til slutningen. Det skyldes, at det er ved slutningen, at man endelig kan overskue hele teksten, og at slutningen ofte giver betydning til de begivenheder, som undervejs virkede tilfældige eller gådefulde. Dermed, siger Brooks, giver litteraturen os mulighed for at opleve noget, som vi er afskåret fra i livet, nemlig en afsluttet, meningsfuld helhed. [...]

Madsens tekster lader sjældent læseren sidde tilbage i fred og ro med en afsluttet, overskuelig tekst. I stedet rækker de ud mod andre tekster, mod nye ord og fortællinger [...].” (Nielsen, "Marianne Kainsdatter Blodet på mine honder" 32-33)

I Madsens værker er rammerne mellem de enkelte værker brudt op, og karakteristisk for forfatterskabet er en markant intern intertekstualitet. Tidligere værker inddrages og gives stadig flere detaljer og vinkler, der ofte kan forandre fortolkningen af dem. ${ }^{15}$

\section{Tid og komposition}

De usædvanlige muligheder i forhold til tid tydeliggøres også med værkernes komposition, hvor det ikke er den lineære fortællings fremdrift, der anvendes som prototype. I Jagten på et menneske får man præsenteret to mulige fremtider, der flettes ind i hinanden. Denne opdeling forklares undervejs i romanen med udformningen af et möbiusbånd:

"Da jeg havde læst det hele igennem tog jeg den lange papirstrimmel, snoede den en halv omgang. Så fugtede jeg den med lidt spyt og klistrede de to ender sammen. [...] Jeg lod fingrene spadsere som en myre hen over papiret hvorpå læserbrevet var trykt, indtil de pludselig befandt sig på bagsiden. For lidt efter at komme om på forsiden igen.” (Madsen, Jagten på et menneske 46)

I Dage med Diam eller livet $i$ Århus må læseren i stedet hele tiden vælge mellem to mulige veje at gå fra det afsnit, han læser, hvilket giver toogtredive afsluttede fortællinger med en række sideordnede og samtidige muligheder. ${ }^{16}$ I et nonlineært værk som dette er det tydeligt, at flere af narratologiens kendte begreber i forhold til tid

I5 Det betyder dog ikke, at de enkelte værker ikke fungerer uden kendskab til forfatterens tidligere fortællinger. Men værkerne bliver rigere ved at forfølge referencerne til de foregående.

I6 For en nærmere analyse af kompositionen i Dage med Diam eller Livet om natten se Nielsens Tertium datur. 
ikke slår til som fabula-sjuzet distinktionen, hvilket Monika Fludernik også har nævnt relaterer sig til en realistisk forståelse af, hvad en fortælling er (Fludernik, Towards a 'Natural' Narratology 334). I Dage med Diam eller Jagten på et menneske kan fremstillingen ikke samles til blot en enkelt fabula eller forestilling. Forestillingen forbliver multiversionel. Alt efter læserens valg af rækkefølge i forhold til fremstillingerne kan en række forskellige fabulaer samles. Det samme gør sig gældende for romanen Tilføjelser, hvor fem hæfter skal kastes ud i en tilfældig rækkefølge, der bestemmer læsningen. Tilfojelser bryder igen med en lineær læsning og opfattelsen af værket som en afrundet helhed. Tilføjelser udfordrer karakteristikken fra Shlomith Rimmon-Kenans klassiske håndbog i narratologi Narrative Fiction (1983) om, at vi altid læser lineært:

"Placeringen af elementer i teksten... må nødvendigvis være rettet én vej og irreversibel, da sproget foreskriver en lineær figuration af tegn og dermed en lineær præsentation af information. Vi læser bogstav efter bogstav, ord efter ord, sætning efter sætning, kapitel efter kapitel og så videre.” ${ }^{\text {17 }}$

I flere værker betoner Svend Åge Madsen en simultaneffekt, som vi så med Den guddommelige farce, men arbejdet med simultanitet er også markant til stede i det værk, Svend Åge Madsen udgav i et samarbejde med Olafur Eliasson til det 5o. Biennale i Venedig i 2003: the blind pavilion. Her er der både en fortælling, der bevæger sig horisontalt, et-linjet som et bånd gennem hele værket, og taler vertikalt med ti mindre fortællingsrum $i$ forskellige genrer og af forskellige forfattere. Ord fra det gennemgående bånd optræder også i de vertikale tekster og skal forsøgsvis læses samtidigt. Det etlinjede bånd gennem bogen kan læses i ring og peger således også mod en uendelig læsning som en endeløs sløjfe. Som Brian Richardson nævner i en kommende artikel "Unnatural Stories and Sequences”, så findes der en række værker, der bryder med klassiske markeringer af et værks begyndelse og slutning:

"I en naturlig eller konventionel fortælling er begyndelser og afslutninger afgørende for at afgrænse omfanget af selve historien [...]. Mange unaturlige fortællinger problematiserer disse grænser." ${ }^{\prime 18}$

Flere af Madsens værker beskriver eksplicit et opgør med en lineær læsning, hvilket Syv aldres galskab også betoner:

I7 Oversat til dansk fra Rimmon-Kenan Narrative Fiction: [...] the disposition of elements in the text... is bound to be one-directional and irreversible, because language prescribes a linear figuration of signs and hence a linear presentation of information about things. We read letter after letter, word after word, sentence after sentence, chapter after chapter, and so on. (Rimmon-Kenan 45)

I8 Oversat til dansk fra Richardson (forthcoming), I4: In a natural or conventional narrative beginnings and endings are essential for demarcating the extent of the story itself [...]. Many unnatural narratives problematize these narratives boundaries. 
"Det kan virke underligt at forfattere, der gerne vil give et dækkende billede af denne verden, i så mange århundreder fortvivlet bestræbte sig på at fange den i én lang, ubrudt tekstlinie. Når kartografer dog for længst havde vist at den nøjagtige afbildning af verden forudsætter en kugleskal.” (Madsen, Syv aldres galskab In3)

I bogen Når man mailer gør Svend Åge Madsen opmærksom på den manglende viden i forskningen i fiktion om værker, der bryder med linearitet: "Har også i dag søgt, $i$ hukommelse, bogsamling og net - uden at finde andre eksempler på nonlineære bøger. Det gør det jo ikke lettere, at der mig bekendt ikke findes nogen betegnelse for fænomenet - så ville det jo være så let at søge - måske fordi det ikke findes? Jeg ville ellers gerne have skrevet globusromanens historie." (Madsen, Når man mailer 244) Som Svend Åge Madsens forgæves søgning også antyder, er der mange eksempler på, at fortælleteorien ikke er fulgt med fiktionens muligheder, fordi realistiske tekster er blevet en art prototype. At tale om relationen mellem fabulasjuzet, forestilling og fremstilling eller begyndelse, midte og slutning giver i flere af Madsens værker som nævnt ingen mening. Som Brian Richardson skriver i artiklen "Unnatural Stories and Sequences", er der i høj grad brug for en videreudvikling af værktøjer, begreber og et vokabularium i forbindelse med tid og komposition:

"Vi har også brug for en udvidet rammesætning for at tage højde for andre former for unaturlige historier, herunder uendelige fabulaer, dobbelte eller multiversionelle handlingsforløb med uforenelige kronologier, i sig selv vage eller ukendte fabulaer; internt modstridende fabulaer: denarraterede fabulaer og gentagende, modstridende versioner af den grundlæggende samme historie. Begrebet syuzhet skal også udvides til at omfatte delvist eller helt variable syuzhet mønstre.”'19

\section{Udgang}

En styrke ved det indledende manifest for en unaturlig narratologi er i første omgang ønsket om at etablere greb og metoder, der tager højde for fiktionens muligheder og artiklens påpegning af det problematiske ved at betegne nogle fortællinger som naturlige. Det er i opgøret med en 'naturlig narratologi,' artiklen for alvor kommer til sin ret og særligt opgøret med forestillingen om, at vi som læsere som udgangspunkt altid vil forsøge at overføre parametre fra den virkelige verden $\mathrm{i}$ vores læsning. Unaturlige fortællinger fordrer, at man som læsere anvender andre fortolkningsstrategier end ved en konventionel, nonfiktionaliseret fortælling, og det er disse fortolkningsstategier, den unaturlige narratologi vil etablere og udforske.

I9 Oversat til dansk fra Richardson (forthcoming), I9: "We also need an expanded framework to account for other kinds of unnatural stories, including infinite fabulas; dual or multiple storylines with inconsistent chronologies; inherently vague and unknowable fabulas; internally contradictory fabulas; denarrated fabulas; and repeated, multiple versions of the same essential story. The notion of syuzhet also needs to be expanded to include partially and entirely variable syuzhet patterns." 
Siden artiklen udkom i Narrative i 20Io, har den indledende definition af unaturlige fortællinger som indeholdende fysiske eller logiske umuligheder været debatteret blandt artiklens skribenter. Stefan Iversen taler i artiklen "Unnatural minds" for en definition af 'unaturlig', der tager højde for konventioner og genre, så det unaturlige bestemmes i forhold til den verden og fortælling, det unaturlige forekommer $i^{20}$ Når det unaturlige ses i relation til genre og til den kulturelle og historiske ramme, bliver det unaturlige variabelt i stedet for en kategorisk umulighed. Men spørgsmålet er, om denne definition, hvor det unaturlige skal bestemmes i forhold til den verden, det forekommer i, ikke også vil afgrænse det unaturlige fra konventionaliserede, men unaturlige fortælleformer som science fiction, fantasy, eventyr, religiøse tekster og billedbøger? En sådan definition vil så bevæge sig over mod Werner Wolfs definition af antiillusionisme, hvor det bliver afgørende, om læseren bliver chokeret over illusionsbruddet, eller om det unaturlige er neutraliseret ud fra en teksts genremæssige eller kulturelle kontekst eller forklares internt som en drøm eller gives videnskabelige eller teknologiske forklaringer som i megen science fiction. Tager man genre og konventioner med som forbehold $i$ en definition af unaturlige fortællinger, bliver realisme let igen en art prototype, der i første omgang bestemmer, hvorvidt fysiske eller logiske umuligheder er interessante at beskæftige sig med. Faren ved denne definition er, at definitionen af unaturlige fortællinger bliver så afgrænset, at den unaturlige narratologi ikke længere kan indfri en af dens mest lovende ambitioner - ambitionen om at give fiktionens muligheder andet end en parentetisk plads i narratologiens fortællemodeller.

Den unaturlige narratologi fremhæver netop $i$ sit indledende manifest narratologiens og fortælleteoriens tendens til at overbetone naturlige parametre. I forhold til tid har man som nævnt anvendt begreber, der korresponderer med virkelighedens tider, og overset de unaturlige tidsscenarier, som eksperimenterende fiktion har udforsket. Ser man igen på et hovedværk i narratologien som Gérard Genettes Narrative Discourse, så nævnes der også muligheder for brud på en mimetisk tidslighed. Men disse eksempler er ofte placeret uden for modellerne, i sidebemærkninger, parenteser og fodnoter. Ved at placere de nonmimetiske eksempler som stadige brud på prototyperne og som unikke undtagelser har man ikke taget højde for deres markante tilstedeværelse i litteraturhistorien.

Men unaturlige scenarier er iøjefaldende i de litterære klassikere. Det gælder unaturlige karaktermuligheder som forvandlingerne i Ovids Metamorfoser (2. f. Kr.-9. e. Kr.), forvandlingen til æsel i Det gyldne asel (I469) af Lucius Apuleius eller forvandlingen til et havvæsen som i The Water-Babies (I863) af Charles Kingsley.

20 "An unnatural mind is presented consciousness which violates the rules governing the possible world it is part of in a way that resists naturalization or conventionalization. Compared to Alber's definition of the unnatural narrative as containing logically or physically impossible elements or scenarios, this definition operates with the looser "violates" rather than the strong "impossible" while linking the determination of something as unnatural to notions of convention and genre: the unnatural is unnatural compared to the naturalness set forth by the specific narrative, not compared to some sort of global naturalness, whatever that might be." (Iversen forthcoming) 
Protagonisten kan være dyr som en kat i E.T.A. Hoffmanns Kater Murr (I820-22), en hund i Nair naturen kalder (I9O3) af Jack London eller en odder i Odderen Tarka (I927) af Henry Williamson. Man kan også møde sin næse eller skygge, der er blevet selvstændige personer som i Nikolaj Gogols Nesen (I836) eller H.C. Andersens Skyggen (I847) eller møde alverdens udgaver af Gud og Satan som Wotan i Mikhail Bulgakovs Mesteren og Margarita (1966) eller Saladin og Gibreel i Salman Rushdies De sataniske vers (1988). Litteraturen er fuld af dobbeltgængere som i Wilkie Collins Kvinden i hvidt (1860), spøgelser som i Slottet $i$ Otranto (I765) af Horace Walpole, ånder som i Åndernes hus (I982) af Isabel Allende og vampyrer som i Bram Stokers Dracula (I897) eller Anne Rices En vampyrs bekendelser (I976). Litteraturen er fuld af gale videnskabsmænd, der kan skabe væsner mellem dyr og mennesker som i H.G. Wells Doktor Moreaus ø (I896) og omdanne lig til robotter i Locus Solus (I9I4) af Raymond Roussel. Der er mulighed for udødelighed som i Melmoth the Wanderer (I820) af Charles Robert Maturin, mulighed for at blive flere hundrede år som i Virginia Woolfs Orlando (I928) eller mulighed for at sætte sin vækst i stå som i Bliktrommen (I959) af Günter Grass eller vokse til det abnorme som den I500 meter lange far i Donald Barthelme The Dead Father (I975). Selv fortælleren kan berette som død i Memórias póstumas de Brás Cubas (I88I) af Joaquim Maria Machado de Assis eller berette som foster i Verden ifølge Garp (1978) af John Irving.

Den litterære fiktion åbner adgang til andre verdner og rum som helvede i Dantes Den guddommelige komedie (I302-I32I), andre planeter som i De udstødte (I974) af Ursula K. Le Guin eller Douglas Adams Håndbog for vakse galakse-blaffere (I979) og til et liv på Antiterra i Vladimir Nabokovs Ada eller Ardor (1969). Der er usædvanlige muligheder for rejser som i Gullivers rejser af Jonathan Swift (I726), Rejsen til jordens indre (I866) af Jules Vernes og tidsrejser som i H.G. Wells Tidsmaskinen (I895) eller Kurt Vonneguts Slagtehal fem (I969). Tiden kan være bagvendt som i Lewis Carrolls Bag spejlet (I87I), der er mulighed for og fornemmelser for fremtid som i William Hope Hodgsons The House on the Borderland (1908) eller adgang til andres minder som i J. K. Rowlings Harry Potter serie (1997-2007) osv. Flere af disse værker kan rubriceres som fantasy, som gotik, børnelitteratur eller science fiction, men det er stadig unaturlige fortællinger, der ikke kan forklares alene med reference til hverdagsfænomener.

Flere af Svend Åge Madsens værker kan også defineres som science fiction som beskrevet i Niels Dalgaards Verdensjongløren (2007), men de er også fulde af unaturlige fortællinger, der fordrer, at vi som analytikere etablerer nye metoder og modeller, der kan tage højde for de rige muligheder, bl.a. i forhold til tid og komposition. Som fornyer af fiktionens muligheder er Svend Åge Madsen uovertruffen, hvilket Lars Bukdahl også markerede i 2007 med indstiftelsen af litteraturprisen Jørgen Fegge Hansen Medaljen - Den Innovative Romanpris opkald efter hovedpersonen i Svend Åge Madsens roman Af Sporet er du kommet fra I984. En pris, der skulle gå til: 
"[...] romaner (herunder genreløse og med konkurrerende genremarkører udstyrede værker, der umiddelbart eller udspekuleret lader sig læse som romaner), der originalt eksperimenterer med romanens form eller måske rettere format [...] oplagte ofre kunne være komposition, fortællerforhold, plot, kronologi, forholdsmæssighed, sammenhængskraft m.m." (Bukdahl "Jørgen Fegge Hansen Medaljen”)

Prisen blev indledt med på forhånd at blive tildelt Svend Åge Madsen 35 gange, hvorefter han vandt den første uddeling af prisen med Det syvende bind fra 2006.

Man siger, at nye teorier ofte tager form efter samtidige litteratureksperimenter som beskrevet i Jan Rosieks artikel "Bogstavelighedens projekt":

"Det er ofte tilfældet, at ny litteraturteori og tekstanalyse udvikler sig i samklang med eller som svar på nye teknikker i den "rigtige" litteratur. Således eksempelvis socialhistorisk analyse som pendant til den store realistiske roman i det I9. århundrede eller formalisme og nykritik som forsøg på at forstå højmodernismens eksperimenter fra begyndelsen af det 20. århundrede." ${ }^{21}$

Ser man på udviklingen af den unaturlige narratologi, synes det at være sigende, at én af frontfigurerne i etableringen af unaturlig narratologi - Henrik Skov Nielsen har skrevet ph.d. afhandling om netop Svend Åge Madsens forfatterskab med Tertium datur - om litteraturen eller det ikke-verende (2003). Det beskrives i opsamlingen på denne afhandling, at "[...] det specielle ved de behandlede tekster ikke placerer dem $i$ en eksklusiv marginalitet, men tværtimod består $i$, at de fremviser noget essentielt ved litteraturen [...]." (Nielsen, Tertium datur 336) Vigtig for såvel afhandlingen som den indledende artikel om unaturlig narratologi er ideen om, at eksperimenterende og konventionsbrydende tekster ikke skal marginaliseres i forhold til fortælleteori, men har paradigmatiske træk for skønlitteraturen og for fiktion.

\section{LITTERATURLISTE}

Alber, Jan. "Impossible Storyworlds - And What To Do With Them." Storyworlds: A Journal of

Narrative Studies I:I (2009): 79-96.

Alber, Jan, Stefan Iversen, Henrik Skov Nielsen og Brian Richardson. "Unnatural Narrative -

Unnatural Narratology: Beyond Mimetic Models?” Narrative 18.2. (2010): II3-I36.

Bukdahl, Lars. "Jørgen Fegge Hansen Medaljen”, Weekendavisen I5. juni 2007.

Bukdahl, Lars. "Priset være priser", Weekendavisen 2I. december 2007.

Dall, Lars Green. Madsens meditationer. En bog om Svend Åge Madsens forfatterskab, Århus: Aarhus

Universitetsforlag, 2008.

Dalgaard, Niels. Verdensjongløren. Svend Åge Madsen og science fiction, Science Fiction Cirklen, 2007.

2I Rosiek I34.

DETTE MATERIALE ER OPHAVSRETSLIGT BESKYTTET OG MÅ IKKE VIDEREGIVES 
Dalgaard, Niels. Dage med Madsen eller Livet i Århus, København: Museum Tusculanums forlag, 1996. Fludernik, Monica.”New Wine in Old Bottles? Voice, Focalization, and New Writing.” New Literary History 32.3 (200I): 6I9-638.

Fludernik, Monica. Towards a 'Natural' Narratology, London and New York: Routledge, I996.

Gemzøe, Anker. Metamorfoser i Mellemtiden, Holte: Forlaget Medusa, 1997.

Heinze, Rüdiger. "Violations of Mimetic Epistemology in First-Person Narrative Fiction." Narrative I6:3 (2008): 279-297

Herman, David. Basic Elements of Narrative, Wiley-Blackwell, 2009.

Herman, David. Story Logic. Problems and Possibilities, Lincoln: University of Nebraska Press, 2002. Iser, Wolfgang. "Tekstens appelstruktur” i Michael Olsen og Gunvor Kelstrup (red.) Vark og laser, Valby: Borgen, I98I.

Iversen, Stefan og Henrik Skov Nielsen (red.). Narratologi, Århus: Aarhus Universitetsforlag, 2004. Iversen, Stefan.”Unnatural Minds.” Red. Alber et al. A Poetics of Unnatural Narrative. Ohio: Ohio State University Press, forthcoming.

Phelan, James og Peter J. Rabinowitz (red). A Companion to Narrative Theory, MA: Blackwell, 2005.

Phelan, James. Narrative as Rhetoric: Technique, Audiences, Ethics, Ideology, Columbus: Ohio State

University Press, 1996.

Phelan, James. Reading Narrative: Form, Ethics, Ideology, Columbus: Ohio State University Press, 1984. Madsen, Svend Åge. Af sporet er du kommet, København: Gyldendal, [1984] I997.

Madsen, Svend Åge. At fortclle menneskene, København: Gyldendal, [1989]1996.

Madsen, Svend Åge. Dage med Diam eller Livet om natten, København: Gyldendal, [1972] I995.

Madsen, Svend Åge. Den ugudelige farce, København: Gyldendal, 2002.

Madsen, Svend Åge. Den usynlige myre, København: Gyldendal, I995.

Madsen, Svend Åge. Det syvende bånd, København: Gyldendal, 2006.

Madsen, Svend Åge. Dr. Strangula: et melodrama i fem akter, København: Arkona, 1985.

Madsen, Svend Åge. Hadets bånd, København: Gyldendal, I978.

Madsen, Svend Åge. Jagten på et menneske, København: Dansklærerforeningen, I99I.

Madsen, Svend Åge. Lad tiden gå, København: Gyldendal, I986.

Madsen, Svend Åge. Liget og Lysten, København: Gyldendal, I968.

Madsen, Svend Åge. Mange sare ting for, København: Gyldendal, 2009.

Madsen, Svend Åge. Maskeballet, København: Gyldendal, I970.

Madsen, Svend Åge. Når man mailer, Fredensborg: Forlaget Bindslev, 2009.

Madsen, Svend Åge. Se dagens lys, København: Gyldendal, r980.

Madsen, Svend Åge. Syv aldres galskab, København: Gyldendal, [1994] I998.

Madsen, Svend Åge. Sat verden er til, København: Gyldendal, I97I.

Madsen, Svend Åge og Olafur Eliasson. The blind pavilion, 2003.

Madsen, Svend Åge. Tilføjelser, København: Gyldendal, I967.

Madsen, Svend Åge. Tugt og utugt $i$ mellemtiden, København: Gyldendal, 1976.

Nielsen, Henrik Skov. “Authors, Characters, and Fictionalized Narration.” Red. Alber et al. A Poetics of

Unnatural Narrative. Ohio: Ohio State University Press, forthcoming a.

Nielsen, Henrik Skov. "Marianne Kainsdatter Blodet på mine hander, Århus: Forlaget Klim, 2009.

Nielsen, Henrik Skov. "Natural Authors, Unnatural Narratives” Red. Monika Fludernik og Jan Alber.

Post-Classical Narratology, Columbus: Ohio State University Press, 2010.

DETTE MATERIALE ER OPHAVSRETSLIGT BESKYTTET OG MÅ IKKE VIDEREGIVES 
Nielsen, Henrik Skov. Tertium datur - om litteraturen eller det ikke varende, Fredensborg: Forlaget Bindslev, 2003.

Nielsen, Henrik Skov.”Unnatural Narratology, Impersonal Voices, Real Authors, and Non-

Communicative Narration.” Red. Jan Alber og Rüdiger Heinze. Unnatural Narratives.Unnatural narratology. Berlin and New York: de Gruyter, forthcoming b.

Richardson, Brian (red.). Narrative Beginnings, Lincoln: University of Nebraska Press, 2008.

Richardson, Brian (red.). Narrative Dynamics: Essays on Time, Plot, Closure, and Frames. Columbus: Ohio State University Press, 2002.

Richardson, Brian. Unlikely Stories: Causality and the Nature of Modern Narrative, Newark: University of Delaware Press, 1997

Richardson, Brian. Unnatural Voices: Extreme Narration in Modern and Contemporary Fiction. Columbus: Ohio State University Press, 2006.

Richardson, Brian "Unnatural Stories and Sequences." Alber et al. A Poetics of Unnatural Narrative. Ohio: Ohio State University Press, forthcoming.

Rimmon-Kenan, Shlomith. Narrative Fiction: Contemporary Poetics, New York: Methuen, I983.

Rosiek, Jan. "Bogstavelighedens projekt” i Skud (red. Anders Østergaard), København: Amanda, I998. Skyum-Nielsen, Erik. Møder med Madsen, Århus: Aarhus Universitetsforlag, 2009.

Walsh, Richard. The Rhetoric of Fictionality: Narrative Theory and the Idea of Fiction, Ohio State University Press, 2007. 